\title{
Cutaneous Melanoma pT1 TNM Finding v7
}

National Cancer Institute

\section{Source}

National Cancer Institute. Cutaneous Melanoma pT1 TNM Finding v7. NCI Thesaurus. Code C88382.

Cutaneous melanoma with a tumor measuring $1.0 \mathrm{~mm}$ or less in thickness. (from AJCC 7th Ed.) 